\title{
Reading the Stockholm riots - a moment for social justice?
}

\author{
Carl-Ulrik Schierup, Aleksandra Ålund and Lisa Kings
}

\section{Linköping University Post Print}

\section{Tweet}

N.B.: When citing this work, cite the original article.

Original Publication:

Carl-Ulrik Schierup, Aleksandra Ålund and Lisa Kings, Reading the Stockholm riots - a moment for social justice?, 2014, RACE \& CLASS, (55), 3.

http://dx.doi.org/10.1177/0306396813509191

Copyright: SAGE Publications (UK and US)

http://www.uk.sagepub.com/home.nav

Postprint available at: Linköping University Electronic Press

http://urn.kb.se/resolve?urn=urn:nbn:se:liu:diva-103871 
This paper is an earlier version of an article published as:

Schierup, Carl-Ulrik, Aleksandra Ålund and Lisa Kings (2014) 'Reading the

Stockholm riots - A moment for social justice’, Race and Class (3), 55: 1-21.

\title{
Reading the Stockholm Riots - A moment for social justice?
}

Authors:

CARL-ULRIK SCHIERUP, ALEKSANDRA ÅLUND AND LISA KINGS, LINKÖPING UNIVERSITY

\author{
What happens to a dream deferred? Does it dry up \\ like a raisin in the sun? Or fester like a sore? ... Or does it explode?” \\ Langston Hughes, 1951
}

\begin{abstract}
This article relates the riots in Stockholm during May 2013 to other instances of urban rebellion across disadvantaged metropolitan neighbourhoods in the North Atlantic region during the past decades of neo-liberal transformation. The authors discuss the consequences of securitization and police repression, institutional racism, the corrosion of citizenship and the structuring of inequality in Swedish cities. Beyond the violence of the recent riots the contemporary Swedish scene also makes visible the emergence of an autonomous, non-violent and organisationally embedded movement for social justice among young people contesting urban degradation and reclaiming the nation in terms of an inclusive citizenship, social welfare and democracy. On this background, the article raises the question whether the Stockholm uprising could possibly be read as a sobering moment of self examination in Swedish politics that could open the space for new political voices.
\end{abstract}

\section{1. 'Riots', 'uprising' or the rebirth of civil society?}

'I have a dream', told Reverend King on his March at Washington fifty years ago. It was a vision of a truly inclusive American nation. Yet, King soon found himself pondering whether the dream was not turning into that very 'Nightmare', which Malcolm X had insisted continued to be the reality of the American Dream for black citizens. 'I watched that dream turn into a nightmare', King admitted in his last Christmas sermon in 1967, 'as I moved through the ghettos of the nation and saw my black brothers and sisters perishing on a lonely island of poverty in the midst of a vast ocean of material prosperity, and saw the nation doing nothing' ${ }^{1}$ Two years earlier tension in the ghettos had exploded in the Watts rebellion and, following years of repression of Black and Latino struggles, the Los Angeles uprising of 1992 struck the nation with awe. This did become a sobering moment in American history; ${ }^{2}$ however, a window of opportunity lost in the euphoria following the fall of the 'Evil Empire', promises of 'The End of History' and seemingly limitless financial pyramid games.

There was a 'Swedish Dream' as well. A dream of changing an ethnocentric 'People's Home' ${ }^{3}$ into a cosmopolitan home of peoples, merging extended rights of citizenship with a political framework divorced from nativist obsession. In a booming reformist spirit of the mid 1970s new policies were conceived in terms of 'Equality, Partnership and Freedom of Choice', boldly rephrasing the revolutionary 1789 trinity into a credo of a liberal multicultural welfare society, ${ }^{4} \mathrm{a}$

\footnotetext{
${ }^{1}$ http://endsandmeans.org/2010/01/18/martin-luther-king-jrs-christmas-sermon-1967/ (2010).

2 R. Gooding-Williams (ed.), Reading Rodney King. Reading Urban Uprising (New York and London, Routledge, 1993).

${ }^{3}$ Social democratic idiom for the welfare state stemming from the 1930s.

${ }^{4}$ A. Ålund and C.-U. Schierup, Paradoxes of Multiculturalism. Essays on Swedish Society. (Aldershot, Avebury, 1991). Republished 2009 as E-Book on http://liu.diva-portal.org/smash/record.jsf?pid=diva2:213706 1991)
} 
particular Swedish 'exceptionalism'. ${ }^{5}$ It was long a dream of hope shared by subaltern others, but with the 2000s, by many of the country's inhabitants, becoming experienced as a nightmare of institutional racism, social disadvantage, securitization and police repression.

Nevertheless, at the time of the rebellion of the les exclues in French suburbia, 2005, Sweden was, still often depicted as 'exceptional'; a positive brand of a liberal multicultural welfare state, and an example for others. Only four years later, in the late summer of 2009, Sweden came, however, to experience its own urban rebellion across suburban districts on fire in the cities of Malmö, Gothenburg and Uppsala. In the spirit of the official denouncement of 'multiculturalism' by leading European politicians, like Merkel, Sarkozy and Cameron, these Swedish riots were largely read by government and media as an expression of cultural deviancy, deficient socialisation of youngsters of migrant and, in particular, Muslim background, and as a provocation to the European heritage and its 'liberal core values'. ${ }^{6}$ Internationally, the 2009 Swedish riots passed relatively unnoticed. Domestically they were already sinking into public oblivion as on 14 May 2013 the killing by the police of a sixty nine years old man in Husby, a socially disadvantaged suburban neighbourhood of 12 thousand inhabitants in Stockholm, sparked - setting off from 19 May - five days of rage among young rioters, with cars, schools, youth centres, local shops, a kindergarten and a police station set on fire. It was, as well, five days of clashes between rioters and police across suburban neighbourhoods of the north western and southern metropolis and with minor incidents also in other Swedish cities through which, according to the acid judgment of one journalist ${ }^{7}$, 'violence and racism within the police organisation was exposed as clearly as a skeleton on an x-ray slide'. Although hardly more violent than the 2009 events, but taking place in the capital and more spread in the urban space, this time the riots became widely read throughout the international press as a deep crisis of a 'Swedish model', having mutated into a hazardous neoliberal experiment. A crisis 'more about economics than immigration' commented Financial Times; and more about social inequality than culture. ${ }^{8}$ Another difference between 2009 and 2013 is the role which politically articulated new urban movements' among young Swedes of, predominantly, migrant background have currently come to play in offering alternative readings of the riots in terms of claims for social justice.

If the riots of 2009 were a Swedish Watts, Stockholm 2013 could be read as its LA-92. A 'dream exploded'; a crisis of neoliberal politics; a sobering moment of truth. But will it be more than a window of opportunity closing? This is the question in focus of the present essay. Its title alludes to Reading Rodney King'; a classical work on race, urban segregation and the structure of cultural, political and economic power in the United States. But we also - in pursuing a line of argument initiated by a project of The Guardian and the London School of Economics under the same heading - hint at similarities between the London 2011 riots and Stockholm 2013. ${ }^{10} \mathrm{It}$ is about a common recent history of gentrification, welfare retrenchment and the proliferation of privately organized social services and education on a broadening range. These are developments common to three decades of neoliberal politics. It is an art in which Sweden has taken learning from Thatcherism and Tony Blair's 'Third Way', but in which Sweden, in some aspects, has also excelled to a degree, so as to become an example to follow - alternatively a warning - to Britain; all depending on the perspective of the observer. Thus, behind the dramatic clashes of May 2013 there is another drama. It is a drama, comments a local Stockholm politician, as shattering as before the riots and 'far before Swedish media or the political elite had any idea of the existence of Husby and of which kind of area it is. A drama of discrimination, poverty, stigmatisation and deep social as well as political cleavages. About a city and a society becoming torn apart.' ${ }^{11}$

\footnotetext{
${ }^{5}$ C.-U. Schierup and A. Ålund, 'The End of Swedish Exceptionalism? Citizenship, neo-liberalism and politics of exclusion', Race \& Class (Vol. 53, no. 1, 2013).

${ }^{6}$ Schierup and Ålund, op.cit.

${ }^{7}$ Johanna Langhorst, 'Husby: Polisen håller i nyckeln’, Feministisk Perspektiv (21 May, 2013)

8 Financial Times, 'The challenges of the Swedish model' (May 26, 2013).

9 Gooding-Williams, op.cit..

${ }^{10}$ Editorial, 'Sweden: reading the riots', The Guardian (26 May, 2013).

${ }^{11}$ Social democratic health politician, Jonas Sjölander on his personal blog. (http://johansjolander.blogspot.se/2013/05/vi-kan-inteblunda-langre-om-husby.html).
} 
We read, consequently, Stockholm 2013 as one among other instances of urban unrest across disadvantaged metropolitan neighbourhoods in the North Atlantic region during the past decades of neo-liberal transformation; a development we shall relate to with a focus on urban policing, the corrosion of citizenship and the structuring of inequality in Swedish society and its larger cities. Our point of departure is an understanding of contemporary riots as uprisings claiming social justice. We see them, using a notion coined by Dikeç ${ }^{12}$, as 'unarticulated' urban justice movements. Yet, beyond the smokescreen of conspicuous violence, the contemporary Swedish scene also makes visible the emergence of an autonomous, non-violent, 'articulated' and organisationally embedded justice movement contesting urban degradation and reclaiming Sweden in terms of an inclusive citizenship, social welfare and democracy. On this background, the question we attempt to raise in this essay, is whether Stockholm 2013 could - rather than signifying the irrevocable passing of a Swedish dream - be read as a peak in the birth pains of a new movement among young people; a movement with visions pointing beyond a looming state of exception? We illustrate in the following how local activist movements - and in particular The Megaphone, situated in Husby - relate to the Stockholm riots, and we conclude by linking into a more general enquiry concerned with the emergence of new urban justice movements.

\section{A state of exception}

Urban rebellions of the last three decades - like Brixton 1981, Los Angeles 1992, Paris 2005, London 2011 and Stockholm 2013 - all appear to be sparked by alleged police brutality and excess exercise of force, causing a general tension - built up through systematic surveillance and daily humiliation - to burst. This is, in each case, combined with a perceived lack of established democratic channels for a just investigation of these 'police incidents' in favour of a common sense representation of events that, at the end of the day, pushes the blame for fatal police action onto the victims or their communities. This may be mediated through racial phantasmagoria, as in the court case following the brutal roadside beating of citizen Rodney King, which provoked the Los Angeles uprising ${ }^{13}$, or through post-colonial exoticism as in the case of the police killing in Husby, Stockholm, here read from the perspective of the local community organisation, The Megaphone:

... in all dailies ... pictures of the balcony where he waves a knife. The 'machete man'... this is a label created so that we the readers shall think: 'oh, he sounds crazy, just as well that the police shot him...

[W] make him a monster. Then he is not worth shit... [M]achete sounds jungle. Sounds non-Swedish.

Even better. ${ }^{14}$

From this perspective of a locally based movement for social justice the killing was experienced as a case of excess exercise of force, carrying a disciplining message to inhabitants of a stigmatised neighbourhood:

How can a team of SWAT-police break into a flat against a sixty nine years old man and kill him?? ...If this had happened against Karl-Erik ${ }^{15}$, sixty nine years, in Kungsholmen ${ }^{16}$ it had been a scandal. Now it will become another story about a mad man in the hood...[L]isten. This is neither the first nor the last time. The police does not exist to serve common people, the workers, the community, the kids... the police is present to protect the political and economic elite: terrify us, discipline us... The police teach us in practice what the school teaches us theoretically: as a poor working man and non-white you are worth less, in Sweden and in the entire world. ${ }^{17}$

It is seen as a murder of a neighbour; an understanding reinforced by the fact that the police initially delivered evidently false information on circumstances around the death of the victim. This led to the rallying of peaceful protests in the local community and later on demands for a

\footnotetext{
12 M. Dikeç in Badlands of the republic. Space, politics and urban policy (Oxford, Blackwell, 2007).

13 Gooding-Williams, op.cit.

${ }^{14}$ Blog. http://megafonen.com/ayna-varfor-dom-finns-lognen-om-husby-mordet-igar/

15 Typical traditional Swedish name with 'white' connotation.

16 A predominantly 'white' high income area in the capital.

${ }^{17}$ Op.cit.
} 
public excuse from the police and for an investigation of the killing by an independent committee, based outside of the Swedish police organisation. ${ }^{18}$ Six days later the first reports emerged of a violent uprising in Husby. The tragic death and the suspicion of unnecessary police violence have been identified, in retrospect, as the spark that lit the flames. The morning after the riots set off The Megaphone invited national media to a press conference that was broadcast in the Swedish national television ${ }^{19}$. In a speech that was read by one of the representatives, and with two eyewitnesses as support, the organization condemned brutality and racist comments by the police in the encounter with youth. But allegedly no dialogue with the police or representatives of the government ensued ${ }^{20}$; a fatal closing down of democratic avenues for the expression of legitimate grievances, reads a blogspot on the Megaphone homepage:

What the police and the large media will brand as general chaos... this what is always written about suburbia and its people is, in reality, a protest against the murder on Monday... definitely not a coincidence, an isolated riot. This remains the only way of expressing frustration when other democratic avenues are closed. Here is organisation, peaceful demonstrations have taken place, but initiatives for dialogue have been left unanswered. The police investigate their own people and will tell that no mistake has been done.... ${ }^{21}$

The feeling of injustice and missing dialogue was hardly repaired with prime minister, Fredrik Reinfeldt blaming the riots (at a press-conference on 21 May, two days after the break out of the riots) on 'angry young men' in need of overcoming 'cultural barriers' and of coming to terms with rules in a democratic society in articulating dissatisfaction and claims. He mentioned the government's persistent efforts to support the development of disadvantaged urban areas and the important role of the local suburban community itself in reinstating order. While Jimmie Åkesson, the chairman of the nationalist-populist party, The Swedish Democrats, compared premier Reinfeldt in a Stockholm on fire with emperor Nero fiddling his violin in a burning Rome ${ }^{22}$ and demanded reinforced security measures against young hooligans, critical voices from the left blamed on the contrary the premier for neglecting 'angry young men's' cry for respect and help, for avoiding any responsibility of the government for the social problems underlying the suburban crisis $^{23}$, for pushing responsibility for solving the crisis onto local communities themselves and for closing his eyes for a deeply problematic Americanisation of Swedish society ${ }^{24}$.

In a cronicle in the daily, Aftonbladet, addressed in solidarity to The Megaphone - their sisters and brothers in 'the eye of the storm' - The Panters, a community-based justice organisation in Gothenburg, found the premier's initial statement alienating disadvantaged citizens from their legitimate belonging to the nation: ${ }^{25}$

Here we stand together. The Panters and the Megaphone. If we did not exist, who should have taken the responsibility of trying to understand the shadows moving in our streets with stones in their hands? These shadows born in Swedish hospitals, registered with Swedish tax-authorities, who went to Swedish schools, spent their time hanging out in Swedish youth centres, and who wish to work in this country, to pay taxes and to die, but whom our prime minister still manages to fabricate into 'foreigners', depicting their action as the result of 'cultural barriers' ... angry young men who need to overcome some cultural barriers and become part of society.

\footnotetext{
${ }^{18}$ Sebastian Chaaban and Patrick Ekstrand, 'Megafonen: ”Poliser kan inte utreda poliser’ Metro (20 May, 2013). Incidents like the killing in Husby are investigated by a special unit within the police organisation.

${ }^{19} \mathrm{http}$ ://www.svt.se/nyheter/regionalt/abc/megafonen-det-var-en-protest-mot-dodsskjutningen

20 See, however, a heavy criticism from within the corpse, seeing an irresponsible use of force as leading to the tragic death of the elderly man in Husby. Police officer, M. Marmgren on his personal (heavily commented) blog, http://konstapelbastian.blogspot.se/2013/08/om-en-mycket-tragisk-dodsskjutning.html.

${ }^{21}$ Blogg, http://megafonen.com/husby-belagrat-av-poliser-ga-hem-det-har-ar-vart-hem/ (13 May, 2013).

22 Parliamentary debate on 23 May. http://www.riksdagen.se/sv/Debatter--

beslut/Fragestunder/Fragestund8/?did=H0C120130523sf\&doctype=sf\#pos=674 .

${ }^{23}$ G. Wikström, chairman for the Swedish Social Democratic Youth League, 'Reinfeldt skjuter ifrån sig det egna ansvaret, Svenska Dagbladet (SvD Opinion, 25 May, 2013).

${ }^{24}$ K. Kielos, 'Reinfeldt är blind inför den nya Sverigebilden', Aftonbladet (June 2, 2013).

25 H. Badpa and M. Solmaz,'Skrivgruppen Pantrarna:Till en nation som brinner', Aftonbladet (June 23, 2013).
} 
This pinpoints the 'irregularisation' of citizenship, ${ }^{26}$ operating through official and popular discourse, legislation, as well as through the everyday practices of security professionals, including the police, military and bureaucrats. We see, with Agiorno Agamben ${ }^{27}$, this as linked to a 'state of exception', understood as the extension of state power through which rights of citizenship can be reduced, surpassed or denied by governments, and in the process of which boundaries between the citizen and the noncitizen become increasingly blurred. Or more specifically; while irregularising citizenship may earlier have been part of a politics of exception, it can now be observed to be part and parcel of the 'normal' working of most states. ${ }^{28}$.

Like other North-Atlantic societies Sweden has, during the last decade, taken essential steps towards a state of exception, ruling in particular in its so-called 'urban development areas' ${ }^{29}$. That is poor suburban neighbourhoods in larger cities with a high proportion of visible minorities, in particular from Africa and the Middle East, stigmatised in terms of 'race', 'faith', 'national origin' or 'immigrant background'. These neighbourhoods have become spots for security concerns and their inhabitants forced to endure continuous police surveillance. ${ }^{30}$ multiple identity checks and stop and search razzias. This condition of surveillance was exacerbated by the so-called REVAproject (Standing for 'Legal Certainty and Effective Enforcement' ${ }^{31}$ ) originating in 2008 as a collaboration between the police force, the migration service and the Swedish prison service, and partly financed by the European Refugee Fund. REVA aims at combating irregular migration through amplified identity checks and deportation. Especially as REVA broadened its regional range to Stockholm in 2013 it has been criticized by anti-racist activists ${ }^{32}$ and described as a step towards setting up a 'police state' ${ }^{33}$. An alleged racial profiling, in connection with identity checks taking place on strategic spots of communication (e.g. Metro stations), has been criticized for targeting not merely 'undocumented', but numerous Swedish citizens of colour. It represents, in effect, a fusion of capillary migration control with surveillance of the stigmatised 'accidental citizen'. ${ }^{34}$

Young activists on the social media describe Husby and similar neighbourhoods in Swedish suburbia as forgotten reservations of joblessness, poverty and lack of perspective for the future, and with the role of the police as counterinsurgency force rather than protector of the local population:

I think about Husby... Black and Blue policemen with gold embroidered crowns come when the state is under threat, not when people die. The police come when people without a passport try to survive; the police come when resistance has passed into desperation. And then we talk about the 'security of the police'. Exclusion from the social security system, deportations and violence... What to do when you never become a part of non-surburbia. Of non-invisibility. ${ }^{35}$

The police speak, from their perspective, of Husby and Stockholm suburbia as a perilous no go zone 'where the next murder of a police will happen', rather than being inclined to talk about the Husby police killing on 14 May. ${ }^{36}$ In line with this, a major study of 'discriminatory policing' in Sweden ${ }^{37}$ concludes that suburbia is described by the police as potentially threatening places, inhabited by youth of 'other ethnic background' with low trust in authorities. Ethnic minorities are at the centre of a growing apparatus for surveillance and securitization, socially marginalised

\footnotetext{
${ }^{26}$ P. Nyers, 'Forms of irregular citizenship', in V. Squire (ed.) The contested politics of mobility: Borderzones and irregularity (London, Routledge, 2010).

${ }^{27}$ G. Agamben, State of Exception (Chicago \& London, The University of Chicago Press, 2005).

${ }^{28}$ P. Nyers, 'The accidental citizen: acts of Sovereignty and (un) making citizenship', Economy and Society (Vol. 35, no. 1).

${ }^{29}$ Regeringskansliet, Urbana utvecklingsområden: en statistisk uppföljning utifrån sju indikatorer. (Arbetsmarknadsdepartementet, 2012)

${ }^{30}$ A. Peterson and M. Åkerström (ed.) Den sorterande ordningsmakten. Studier av etnicitet och polisiär kontrol. (Lund, Bokbox, 2008).

${ }^{31}$ Swedish: Rättssäkert och effektivt verkställighetsarbete.

${ }^{32}$ E.g. Pouran Djampour. http://www.irr.org.uk/news/we-need-to-end-racism-now-period/ (May 9, 2013).

33 Daniel Wiklander, http://debatt.svt.se/2013/02/18/revas-rasjakt-pa-papperslosa-smakar-polisstat/ (SVT, 18 february, 2013)

${ }^{34}$ Term coined by Nyers op.cit.

${ }^{35}$ http://thewhoryspirit.wordpress.com/2013/05/20/jag-tanker-pa-husby/

${ }^{36}$ A. Johansson, 'Efter upploppen i Husby: ”Här kommer nästa polismord att ske”', Aftonbladet (20 May 2013).

${ }^{37}$ A. Peterson and M. Åkerström, op.cit.
} 
places have become stigmatised and criminalised and it is enough to live in or to be present in a certain area in order to be in the focus for control.

In effect, the critical idiom of 'policing the crisis' holds as substantial a relevance as ever. A permanent tension between the police and young people has built up across a disadvantaged Swedish suburbia, which appears to explain the silence of the police organisation, facing the demand for explanation and dialogue following the Husby 'incident'; a boiling cauldron, a hotbed for rebellion, but hardly a seedbed for dialogue. Changing the meaning and quality of police work appears, consequently, an essential prerequisite for any political reform. The police are not in themselves the deep source of the conflict, nor its solution. But the 'bluejackets' are a symbol of a perceived racist society and the most visible targets for resentment and detestation in their function as the praetorians guarding speculative financialisation, welfare retrenchment, grapping of the commons and segregative processes of urban transformation; practices producing new geographies of inequality and undermining trust in the promises of a regime that still represents itself as the custodian of liberal democracy, prosperity and equal opportunities. ${ }^{38}$

A statement dictated in 2009 on pieces of a cardboard box for cigarettes by thirty youngsters standing on a square in Backa, a suburb to Gothenburg, trying to explain why they were throwing stones on the police, appears indicative:

We stand here every day. Poseidon, the tenants' association, the police, the authorities, see us standing here, but do not care about the matter. Jobs or some effort from the municipality or the social welfare service is needed. The authorities have seen us growing up and standing here for five or six years, but nothing is done... [T]his is our only way to be seen... ${ }^{39}$

\section{Economic restructuring, welfare retrenchment and urban transformation}

A post Second World War 'Swedish model' enjoyed international reputation for combining a dynamic economy and an active labour market policy geared towards occupational upgrading and free access to all education ${ }^{40}$ with an extended tax-financed public service sector aimed at the banning of poverty, at forging social mobility for the working class and, not least, stimulating female labour market participation and gender equality. In effect this resulted, during the 1950s to 1970s, in a seemingly stable trend towards diminishing social inequality, making Sweden one of the most equal societies in the OECD area ${ }^{41}$. Since the mid 1970s this reputation has been merged with the fame of harbouring one of Europe's most successful policies for the incorporation of immigrants, long appearing to promise a development of what has been laid out as the ideal model of a multicultural welfare society. ${ }^{42}$ It involved an easy access to naturalization of immigrants, unconditional access to full social rights and equity concerning employment based on residence, ${ }^{43}$ fast access to political participation and the recognition of particular identity claims in terms of ethnicity and culture. To this was added Europe's most welcoming policy of asylum. For immigrants and new ethnic minorities, promises of the model did, in several aspects, remain but a dream in a society with, still, a marked actual inequality - structured along an intersection of class, ethnicity and gender. Most significantly a persistent dogma insisting that a strong welfare state and an active labour market policy would as such guarantee equal treatment and equal opportunities in the labour market - a stance long argued by both unions and employers - caused a problematic absence of a sturdy anti-discrimination legislation. Nevertheless, prevailing institutional practices would, as such, guarantee even the most disadvantaged a basic social security. ${ }^{4}$

\footnotetext{
${ }^{38}$ Critical voices from within indicate that there is a clear awareness of this within parts of the Swedish police force. See, e.g., T. Martinson in the daily, Expressen (http://www.expressen.se/nyheter/polisman-om-husby-jag-vill-inte-langre-tiga/ ).

${ }^{39}$ Göteborgsposten, 'Arbetslöshet och trakasserier' (20 August, 2009).

${ }^{40}$ Including all higher education.

${ }^{41}$ M. Johansson, 2006, Inkomst och ojämlikhet i Sverige 1951-2002 Stockholm: Institutet för framtidsstudier, Report, 2006:3

${ }^{42}$ E,g, J. Rex, The Concept of a Multicultural Society (Warwick, Centre for Research in Ethnic Relations, 1985, No. 3) and S. Castles, 'Democracy and multicultural citizenship: Australian debates and their relevance for Western Europe', in R. Bauböck (ed.) From Aliens to Citizens: Redefining the Status of Immigrants in Europe (Aldershot, Avebury, 1994).

${ }^{43}$ D. Sainsbury, 'Immigrants' Social Rights in Comparative Perspective: Welfare Regimes, Forms in Immigration and Immigration Policy Regimes', Journal of European Social Policy (Vol. 16, no. 229)

${ }^{44}$ Ålund and Schierup op.cit., Schierup et.al., 2006, ch. 8, Schierup and Ålund. op.cit..
} 
However, from beginning of the 1990s both the political playing field and basic social conditions have changed substantially. A recession at the threshold to the 1990s was followed by austerity policies. A new 'Third Way' social democratic regime was to favour neo-liberal monetarism over Keynesianism and full employment. Unemployment rose to levels unseen since the great depression of the 1930s; from 1.5 percent in 1989 to 8.1 percent in 1993, but among foreign born from 3,5 per cent to 24 per cent during the same period, and with disproportions in the level of unemployment particularly striking for persons born in Africa, Asia, and European countries outside the EU, as well as for their Swedish born children. ${ }^{45}$ This is a condition essentially prevailing until today, with an unemployment that is in particular concentrated among youth $^{46}$. A parallel reorientation of Swedish labour market policies along lines similar to US or UK-style workfare regimes and more restrictive access to supplementary welfare benefits and with the rise to power from 2006 of centre-rights governments - stringent limitations in the coverage of public health insurance, has contributed to the production of a marginalised reserve army exposed to the market discipline of precarious low wage niches, and, pushed from the centre to the periphery of the welfare system, into a casualised secondary labour market and a degraded informal sector. ${ }^{47}$

The burden of change weighted asymmetrically on disadvantaged suburban areas around the large cities, officially designated as 'urban development areas ${ }^{48}$, with a large proportion of newly immigrated and citizens with their ethnic backgrounds outside of the region of the pre 2004 EU15. Participation in the formal labour market is significantly lower in these areas than the Swedish average, or the average in the large cities, and the average income among those who do have work significantly lower ${ }^{49}$. In Husby, for example, the employment rate is close to 24 percent lower than in the greater Stockholm region, and most of those who work hold low income jobs. ${ }^{50}$ What has caused most worries among politicians and social workers is, however, the large number of young people who neither hold any type of formal employment, nor are involved in education. ${ }^{51}$ Whereas the national average is 20 percent among youth between 20 and 25 years of age, the average of young people outside work or education in the urban development areas is the double, but with rates close to 50 or 60 percent in certain disadvantaged areas. The child poverty rate in these areas varies between 28 and 62 percent. ${ }^{52}$ Adding to the forces of marginality, a sweeping deregulation of the public school system - likewise launched from the early 1990s with the explicit motivation of stimulating 'diversity' and civil society initiatives - has created an open playing field for speculative risk capital and insider deals, but have caused a widened gap in educational opportunities and school results, between high income areas, and deprived suburban areas. ${ }^{53}$

The brighter side of this brusque transformation, for some, was a stunning rise of corporate profits from the mid 1990s, which together with a marked redistribution of income was to bestow Sweden the dishonourable position it has held to this day, of being the OECD member state with the fastest growing index of inequality; ${ }^{54}$ a trend exacerbated by consecutive tax reductions, introduced by centre-right governments from 2006 onwards. This, and Sweden's coming out of the 2008 recession more favourably than most of its fellow travellers in a crisis ridden European union, has been a cherished thematic for international business media. As late as February 2013, The Economist, could refer to Sweden as 'The next supermodel' in terms of reduced public

\footnotetext{
45 See further, Schierup et. al. 2006.

46 SCB 2013 http://www.scb.se/Pages/Product__23262.aspx and Eurostat 2013.

(http://epp.eurostat.ec.europa.eu/statistics_explained/index.php/Unemployment_statistics.

${ }^{47}$ E.g. Schierup, Hansen \& Castles, op.cit.and Schierup \& Castles, op.cit..

${ }^{48}$ Regeringskansliet, op.cit..

${ }^{49}$ R. Anderssson et. al., Contextualising ethnic residential segregation in Sweden: welfare, housing and immigration-related politices

(Research report. Helsinki: Helsinki University, 2010).

${ }^{50}$ Regeringskansliet, op.cit., p. 16.

${ }^{51}$ Regeringskansliet, op.cit., pp.

52 T. Salonen. Barnfattigdomen i Sverige (Årsrapport 2012. Stockholm: Rädda

Barnen, 2012)

${ }^{53}$ E.g., P. Kornhall, Barnexperimentet. Svensk skola i fritt fall (Stockholm: Leopard förlag, 2013).

54 Albeit starting out from a remarkably low level compared to countries like the UK or the US. See, e.g., OECD, Divided we Stand (Paris, OECD, 2011) and OECD, Crisis squeezes income and puts pressure on inequality and poverty, http://www.oecd.org/social/inequality.htm (OECD, 2013).
} 
spending, the cutting of marginal and corporate taxes and introducing publicly financed, but privately organized, social services on a broad range. ${ }^{55}$ Yet, the 2013 riots appear to have scratched Sweden's glory in the corporate world. While The Economist found the riots 'A blazing surprise' ${ }^{56}$ disrupting the Scandinavian 'idyll' by 'arson and unrest', and wondered whether the 'integration of immigrants' is failing, ${ }^{57}$ the Financial Times pondered that it is time for Sweden to question the range of privatisation and market driven development. Sweden went too far, from a social democratic display window to a neoliberal experiment, and needs to find a balance. The Husby riots were a symptom. Politicians must understand and address the causes for a galloping inequality, both in terms of income distribution and deregulation of public services, with the consequences of the school reform for deprived suburban neighbourhoods being particularly worrying. ${ }^{58}$ Wall Street Journal found the riots spotlighting a growing socioeconomic rift and 'dealing Sweden's reputation for equality and tolerance a severe black eye' ${ }^{59}$.

Thus the Stockholm riots set international focus on the geography of urban inequality with its most conspicuous appearance in larger cities like Malmö, Gothenburg and Stockholm. Increasing social polarization is a general contemporary trend in cities across the world, however, with an immense variety of configurations. In the United States and the United Kingdom the term 'suburbia' denotes, for example, urban decongestion, lower residential density and private home ownership. In Sweden and France, in contrast, suburbia (the Swedish förorten and the French banlieu) signifies deprived municipal housing areas inhabited by a major proportion of poor immigrants and their offspring together with other among society's most disadvantaged.

In effect, it is essential to relate Swedish urban development to the historical contexts and the origins of segregation. In the late 1960s and the early 1970s, the ambitious suburban municipal housing program - 'The One Million Dwellings Programme' (Miljonprogrammet) - was targeted at raising the general standard of living and providing affordable housing. Newly build suburban neighbourhoods, including Husby, were meant to symbolize the 'pinnacle of Swedish modernity', but soon came to represent the shortcoming of modern social engineering. Especially since the 1990s, several of these suburban areas have been transformed from being 'mixed neighbourhoods' to low income areas with a majority of inhabitants of 'migrant background'. ${ }^{60}$

Seen in this perspective, the riots of 2009, followed by those of 2013, signify the debacle of decades of Swedish urban policy, including a national, so-called 'Metropolitan Policy' on a grand scale, adopted by parliament in 1998. ${ }^{61}$ The new Metropolitan Policy was marked by important flaws, however, among other avoidance of a focus on matters of racism and discrimination, linked to the wider political economy and structure of power in the larger cities. ${ }^{62}$ More conclusively, grand strivings at urban restructuring and social engineering for combating growing urban segregation and social inequality have largely been steamrolled by major policy trends in the 2000s: a development from 'welfare' to 'workfare', from public sector and civil society partnerships to market driven projects, and with understandings of marginality becoming displaced from institutional and structural causality to a focus on individualised problems and solutions. ${ }^{63}$ This has taken place in tandem with emerging politics of securitization, the representation of suburbia as cradle of religious fundamentalism and as a threat to democracy and liberal 'core

\footnotetext{
55 The Economist, editorial, 'The next supermodel’ (February 2, 2013).

${ }^{56}$ The Economist, editorial, 'A Blazing surprise’ (June 1, 2013).

${ }^{57}$ The Economist, editorial, 'Is the integration of immigrants failing?' (25 may, 2013).

${ }^{58}$ Financial Times, op.cit.

${ }^{59}$ Wall Street Journal 'Sweden riots spotlight growing economic rift' (26 May, 2013).

${ }^{60}$ U. Ericsson. I, Molina and P-M, Ristilammi. Miljonprogram och media. Föreställningar om människor och förorter (2002. Stockholm/Norrköping: Riksantikvarieämbetet;

Integrationsverket).

61 Prop. 1997/98: 165. Utveckling och rättvisa. En politik för storstaden på 2000-talet. Stockholm:

Regeringskansliet.

62 See, e.g., the study by Adiam Tedros, Utanför storstaden. Konkurrerande framställningar av förorten i svensk storstadspolitik, dissertation, Gothenburg University (2008).

${ }^{63}$ Schierup et.al., op.cit. (2006).
} 
values' ${ }^{64}$ Reflecting on this development of the contemporary Swedish cityscape, argues Ove Sernhede - professor in social work - that what was earlier seen as problems to be addressed through social policy, today tends to become matters for police intervention. ${ }^{65}$

Police violence is indeed referred to by youth as a continuous pattern that triggered the riots, yet on the background of a structurally contingent urban geography of inequality, expressed, among other, in ethno-racial terms. But it is not just the concentration of poverty and unemployment that is the background to youth unrest, but feelings of neglect and injustice, as here summarised in a video message by Emory Douglas, former minister of culture in the Black Panters, dispatched to its present-day sister organization, The Panters of Gothenburg:

[A] valid request turned into a nightmare and ignited the many decades of frustrations and neglect that imploded into the destruction of the community... frustration borne from a long train of abuses and neglect from an unjust system which has never shown equal respect for all of it citizens. You must join together to correct injustice, heal the community, and educate the young people to the real power they have because they are the future right now. ${ }^{66}$

\section{Advanced marginality and its contestation: From 'noice' to 'voice'}

Out of changing Swedish cityscapes of the third millennium a new vigorous trans-ethnic mobilization of suburban youth is coming to light. Movements of young suburbanites articulate, discursively and in political practice, the anguish of spatial marginality with concerns of social inequality, racism and quests for justice. They can be designated as an urban justice movement. Their distinguishing mark is that place is base for mobilization. The notion of 'suburbia' (förorten), imagined and lived, is addressed in terms of collective identity, targeted at raising consciousness on processes of marginality and mobilising power to influence politics through canonised as well as unconventional modes of action.

From this perspective, we see the contemporary city as constituting a strategic terrain for conflict and contestation, with 'advanced marginality' - a term introduced by Loïc Wacquant ${ }^{67}$ - as point of departure for exploring causes and implications of contemporary urban geographies of poverty and precarisation. Mustafa Dikeç ${ }^{68}$ critically deepens the meaning of 'advanced marginality' in bringing forth that deprived neighborhoods may be actually sprawling with collective grassroots activism. Reflecting on French urban policy Dikeç emphasizes that space and place cannot be considered as given, but are produced by multiple practices and discourses. Suburban multiethnic districts are, on the one hand, increasingly constituted as 'badlands' in public discourse and, related to this, exposed to repressive forms of state intervention. But they are also potential or actual sites for political mobilization driven by democratic ideals. He sees contemporary youth rebellions in France, but also in European cities in general, 'not merely as intrinsic acts of violence'. ${ }^{69}$ They represent responses to structurally embedded processes of segregation, unemployment, ethnic discrimination and restructuring of the welfare services. Urban revolts are, he argues, 'justice movements'; that is movements questioning spatially and socially pronounced injustices, embedded in wider political contexts. Dikeç emphasises the importance of recognition of activist groups as public 'voice' - articulated movements aiming for deliberative dialogue - often rendered invisible in public discourse, in favour of attention to the 'noice' of spectacular revolts.

A pilot study in 2012, conducted through examination of internet sites, participant observation at local gatherings, conferences and demonstrations, individual interviews and interactive group discussions, ${ }^{70}$ exposes a variety of orientations and forms of organization among new urban justice

\footnotetext{
${ }^{64}$ Schierup \& Ålund, op.cit (2011).

65 O. Sernhede 'Curtailed citizenship, social pedagogic and informal learning processes in youth culture', in L. Eriksson \& T. Wiman, Learning to fly (Gothenburg: Daidalos, 2010) .

${ }^{66} \mathrm{http}: / /$ megafonen.com/emory-douglas-legend-fran-svarta-pantrarna-ger-sin-bild-av-forortsrevolten-i-sverige/.

${ }^{67}$ Wacquant 2008, op. cit.

${ }^{68}$ Dikec, op. cit.

${ }^{69}$ Op. cit., p. 148.

${ }^{70}$ L. Kings \& A. Ålund, 'Counter narratives of suburban activism', (2013 in progress).
} 
movements in Sweden. They range from strictly localized initiatives and spectacular cultural events to the long term building up of activist platforms with local, national and international ramifications. FORIX, Förorternas Riksdag (The Suburban Parliament), is among the more spectacular initiatives, FORIX functioned as a forum for critical debate, a scene for alternative suburban cultural expression and a rallying point for urban justice movements across Sweden. In the wake of FORIX' ambition to gather organizations, activists and network under a single umbrella a new think tank, För Orten (For the Local) ${ }^{71}$, was launched in 2013. Miljardprogrammet (The Billion Program) is another broad suburban initiative. It attempts to build a national network for grassroots mobilization among inhabitants of the Million Dwelling Program aimed at neighborhood renewal.

Among new numerous locally rooted community initiatives and activist networks, the Megaphone and the Panters - the interventions of whom in the debate on the Stockholm riots, we have referred to in the beginning of this essay - stand out as the most organized, politically articulated and influential. The Megaphone (Megafonen) originally started its activities in Husby, Stockholm, where the 2013 riots took off. They fly a slogan inspired by past Latin American antiimperialist struggles: 'A united suburb can never be defeated'. The Panters took off from the deprived neighbourhood of Biskopsgården in Gothenburg. While deriving their identity marker from past Black struggles in the United States, living legends like Bobbie Seal and Emory Douglas are a contemporary source of inspiration in their work.

Both The Megaphone and The Panters combine local rootedness with national and international networking. They forge alliances with other civil society actors, and articulate goals and visions in broad public contexts. During the past five years, both of these organizations have expanded geographically and in numbers of sympathizers, activists and participants. The Megaphone has spread its activist network to wider areas in suburban Stockholm and The Panters have extended its activities to Malmö and connected to similar urban initiatives in Copenhagen. Education through individual assistance, study-groups, movie seminars and discussion meetings - directed towards both local youth and adults - are basic to their work. Both the Megaphone and the Panters operate as critical voices in the mass media, and are present in public demonstrations and on conferences on urban issues. They act as watchdogs and pressure groups concerned with political and administrative decisions on the local, city and national level. Autonomy in relation to party politics, other civil society organizations and the state is seen as essential, both in terms of legitimacy and actual capacity for defining independent agendas.

For our present purpose The Megaphone is of particular interest, due to its location in Husby, Stockholm, and as a case that exposes the interconnection of place based livelihoods, emerging modes of civic agency and their wider structural-institutional conditionality, not least in connection with the 2013 riots. The organisation was founded during the Winter of 2008-09 as a community reaction to reporting on the fatal assault on and death of the Husby citizen, Ahmed Ibrahim Ali, nicknamed 'Romário'. Romário was a well known football player in the area but was - through media reception of the murder seen as transmitting a habitual stereotypical imagery of young suburban males - represented as a criminal and a gang-member. During the same period also another spectacular assault caused the death of a young man, Riccardo Campogiani, in central Stockholm. Media reporting on this murder, where victim as well as perpetrator came from a more well off backgrounds in a high income area, took completely different forms and also resulted in public denunciation and a manifestation against street violence convening more than ten thousand people. It was upon the frustration over what was, in the Husby youth community, perceived as a discriminatory representation of the murder of Romário compared to the murder of this other young man, that the Megaphone took off as voice of the suburb challenging dominant media's perceived stigmatising stereotypes on suburbia; a new 'megaphone' for voices seldom heard.

With a self-understanding as part of Sweden's 'new popular movement' (den nya folkrörelsen) The Megaphone formulates its objectives as follows: working for social justice in Sweden through organising young people in the suburbs in a society where everyone has equal opportunities and

71 https://www.facebook.com/TankesmedjanForOrten. 
are included in all important political decisions; a society with collectively owned municipal services as opposed to a massive clearance sale of public property; the making of a society for all free from racism, sexism and class-oppression through 'mobilising the power that repression in suburbia gives birth to'. ${ }^{72}$

This self-understanding in terms of 'the new popular movement' was also reported by the Swedish journalist Karin Elfving, ${ }^{73}$ focusing on the attraction of The Megaphone for suburban youth with respect both to symbolic power and identity formation. She concludes that belonging and identity has another meaning for youth in Husby than for their immigrated parents, below exemplified through bits from her dialogue with young people in the community

'What am I - Kurd, Swede or Eritrean? This we have all gone through and this is what unites us', explains Ailin Moaf, young activist from Husby. 'I do not as my parents, feel at home in the Persian association, and many more should'nt in the Somalian or the Kurdish. I guess The Megaphone is what is felt as a home for us'. She goes on explaining that it is the very experience of injustice and a common interest in Husby that forges a strong sense of community and belonging focused on The Megaphone, together with the feeling of power to make a change. Elfving refers further to another Megaphone activist, Basar Gerecci, who finds that what he experiences as an ever sharper forging of boundaries between people and between urban neighbourhoods can lead to similar movements elsewhere. But for a movement to succeed an organisational platform and serious work is necessary, as well as people prepared to engage themselves.

The popular educational program Harakat, run by the Megaphone in collaboration with the Red Cross in Stockholm, is a case in point. Support by established organisations, as well as participation by prominent researchers and politicians, have strengthened its legitimacy. The Megaphone's activities include, moreover, demonstrations against the closing down or the subcontracting to corporate entrepreneurs of public health and care service in the suburbs of Stockholm, interventions in controversies over ongoing makeover and privatisation of municipal housing ${ }^{74}$ together with engagement in dialogue with politicians on urban renewal; often against heavy odds. Currently its activities are broadened from being focused on local community issues towards a national engagement in support for asylum seekers and irregular migrants involving a solidarity network confronting the REVA police action against undocumented. ${ }^{75}$

Altogether, in spite of a controversial public image, the development of The Megaphone demonstrates basic elements in the making of a social movement: organisational platform, continuity, collective identity and legitimacy. Its public visibility was significantly strengthened in connection with the Stockholm 2013 uprising where The Megaphone took a major stride into the wider national and international mediascape. They managed to capture a noticeable platform in the national media, stubbornly working to make the public and Swedish politicians look beyond burning cars in favour of opening eyes for unequal citizenship and structural explanations to what was taking place ${ }^{76}$. Already the day after the killing on 14 May the Megaphone issued critique of a perceived bias in media reporting on the incident, organised a peaceful public demonstration, and invited the police for dialogue with the local community. Thereafter, after calling a pressconference already the day after the setting off of the riots, they became recognised as a herald of suburbia. ${ }^{77}$

The Megaphone stresses their mission as democratic and non-violent: ${ }^{78}$ 'We in the Megaphone together with others from the area have... taken advantage of our democratic rights in order to gain

\footnotetext{
72 http://megafonen.com/om/politiskt-program/.

${ }^{73}$ K. Elfving, 'Inte bara snack i megafonen', Svenska Dagbladet (24 October, 2012).

74 http://www.mitti.se/?p=48617

${ }^{75}$ E.g., http://megafonen.com/ai1 ec_event/demonstration-mot-reva/?instance_id= and http://debatt.svt.se/2013/03/14/hassen-khemiri-spracker-myten-om-sverige-som-ett-antirasistiskt-land/

${ }^{76}$ http://www.aftonbladet.se/kultur/article16826717.ab, http://www.aftonbladet.se/kultur/article16861701.ab

77 http://www.svt.se/nyheter/regionalt/abc/megafonen-det-var-en-protest-mot-dodsskjutningen

78 http://megafonen.com/husby-belagrat-av-poliser-ga-hem-det-har-ar-vart-hem/
} 
a hearing and making the police answer for their action', they argue, 'We claim social justice, but they answer with batons and dogs'. A detailed report from the homepage reads: ${ }^{79}$

As a fusty smell of poisonous smoke spread across the neighbourhood many of us went into the streets of Husby to find out what had happened. There we were met by masked police in armour with dogs and batons. The police went to attach against local people who had gathered on the square. Defenceless people were beaten by batons and chased from their domicile. We simply did not have any right to be there... outside of our own homes. We also did not have a right to question the methods of the police as their response was to run after us again from different directions with their dogs and batons. Without judgment the police went on to beat young people, parents who had gathered on the spot and social service field workers from the community. People who had chosen to discuss, argue and demonstrate against police violence now had batons hurled against them. Then it became obvious that the violence of the police was directed against all in Husby."

A public response from the police organisation concerning the killing of the 69 years old man in Husby on 14 May was given only on 7 August, when the police investigation was closed with the verdict that the incident in Husby was an act of 'self-defense' of the policeman who pulled the trigger. Currently, the director of the public prosecution authority, who officially closed down the investigation, has been reported to The Ombudsmen for Justice for what is described as an inferior investigation.

\section{From 'exceptionalism' towards 'state of exception'?}

An alleged 'Americanization' of Sweden's handling of its urban question is still far from looking like the mass incarceration invested in the transformation of America's 'hyper-ghettos' into the 'surrogate ghetto' ${ }^{80}$ of its huge prison-industrial complex. Comparing with the United Kingdom the legal aftermath to the Stockholm riots appears restrained. In Sweden about 90 percent of the reported incidents that according to the Swedish police where related to the riots of 2013 have been closed down. Only a handful of suspects have at the time of writing been brought to court and have received comparatively mild sentences ${ }^{81}$. This is compared to 2,700 persons brought to court across England after the 2011 riots, and of these many of them receiving long prison sentences. ${ }^{82}$ It is a difference of such a scale that it hardly appears explainable by the larger extent of the London and UK riots than the Stockholm riots, nor by the fact that the Stockholm riots did not involve looting like in the case of the UK ones. While in UK the dominant political reaction following the riots points towards more and tougher policing, this has not been the case in Sweden. Violence as a means of expressing social grievance was certainly universally denounced as 'completely unacceptable' by speakers across the entire Swedish political spectrum, but apart from the populist Sweden Democrats, demanding more hardy police action, the political debate on the riots has not been dominated by arguments for solving the urban crisis through police repression or criminalising the young. Finally, official Sweden 2013 is hardly on a par with official Britain's branding of the London 2011 riots in terms of 'blaming the breakdown of families and lack of character in the young, rather than structural issues'. ${ }^{83}$

The dominant political understanding of the 2013 uprising does appear to signal a sobering moment of self examination. The tone was set by, among others, the chairman of Sweden's powerful social democratic party, Stefan Löfven. Commenting on Facebook on the first night of the Stockholm riots he saw them as a reminder of a 'responsibility resting heavily on all of us, who are working politically', implicating that the discussion of the riots should focus on finding 'concrete solutions to the real problems' of coming to grips with youth unemployment, of providing educational opportunities for everybody and of creating sustainable housing and urban milieus. ${ }^{84}$ Even though the right and the left differ in terms of their concrete policies for redressing

\footnotetext{
${ }^{79}$ Op.cit.

${ }^{80}$ See, L. Wacquant, 'The new "peculiar institution". On the prison as surrogate ghetto', Theoretical Criminology (Vol. 4, no. 3, 2000).

${ }^{81}$ SR, Få ställs till svars för Stockholmskravaller (Ekot Sveriges radio, 29 july)

${ }^{82}$ Lee Bridges, 'Four days in August: the UK riots' in Race \& Class (Vol. 54, no. 1, p. 7). (Bridges 2012)

${ }^{83}$ Quoted from the critical analysis by Bridges, op.cit., p $1 .$.

${ }^{84}$ S. Löfven on Facebook 20 May, 2013 (https://www.facebook.com/stefanlofven/posts/571823579525207).
} 
poverty and urban marginality, this is a general reason that has resonated across the political leftright divide; among other permeating a major debate on the riots in the Swedish parliament, held on 31 May 2013. ${ }^{85}$ Moreover, - in contrast to the political reception of the Swedish 2009 riots - in 2013 there has', with some exceptions, been an absence of reference to 'problems of immigration'. There has also been an absence of focus on 'deviant cultures' and 'deficient socialisation'; a state of discourse making premier Reinfeldt, talking the talk of 'cultural barriers' in his initial comment on the riots, appear beyond the pale of current Swedish political standards. The rioters are read, across the political spectrum, as 'youngsters' or 'young men' rather than 'immigrant', 'ethnic minority' or 'Muslim' youth. Rather than fuelling further the existing stigma of 'suburbia' there has been a general political appraisal of an engaged local civil society in Husby and other Stockholm suburbs, for its important role in resting violence.

Nevertheless, together with this apparent shift in Swedish political discourse, what seems to escape the debate is an explicit recognition of the detrimental impact wrought by an actually existing structural racism and institutional discrimination on Swedish suburbia and on the legitimate rights of its citizens; and, more generally, exacerbating polarization between metropolitan livelihoods in centre and periphery and maiming trust in democracy and social justice among the most disadvantaged. A deafening silence across most of the mainstream political spectrum, answering The Megaphone's loudly spoken demand for an independent investigation of the Husby killing, appears an ill omen. The closing of the investigation on this 'police incident' by 7 August with an unconditional freeing of the policeman who shot 'the man with the knife' in the head at short distance on 14 May, from any guilt or suspicion, indicates that Sweden has some distance to travel in coming to grips with a looming state of exception.

We have argued that the root causes of the rebellion are not in city districts like Husby or in Stockholm, Malmö and Gothenburg as segregated cities as such, but in general problems of social polarization in terms of an intersection of space, race, income and power. Unrest in Stockholm suburbia has slackened but beneath a calmer surface bubbles a constant frustration. While we have focused on youth unrest in 2013, we will finally stress the need to contextualize the complex embeddedness of civil society activism; a need to relate urban activism to the actually existing forms of advanced ethnic and residential segregation, marginalization and social exclusion of racialised minorities; polarization of income distribution related to neo-liberal restructuring and welfare retrenchment; securitization and the scaling up of police violence. On this background an obvious lack of democratic space for promotion of alternative voices from suburbia and its citizens' influence in mainstream political fora has, in Sweden like in other EU Counties, become a challenge to, and puts in question, a 'flattering and valorizing picture of superior Europen values and a democratic, open and tolerant way of life". ${ }^{86}$

While often denied voice or being stigmatized through negative fame in dominant national media, The Megaphone of suburbia has yet become a symbolic space for resistance, for public voice and for belonging. Civil society activism - like that embodied in The Megaphone - has become a source of identity, solidarity and resistance, particularly among youth in multiethnic suburbia. Creating numerous links to sister organizations, the short history of The Megaphone indicates the birth of a new networked popular movement (folkrörelse) as justice movement. Thus we have argued that new autonomous actors within civil society are demanding their place among Swedish popular-movements. Through their focus on urban social justice, through their active presence as critical public voices in mass media, and through knowledge production and public manifestations, they transpire as a new political subject different from established civil society actors. By doing so, emerging youth justice movements create new agendas for the right to the city as well as to rights of citizenship.

\footnotetext{
${ }^{85}$ http://www.riksdagen.se/sv/Debatter--beslut/Ovriga-debatter/Ovrigt/Ovrig-debatt/?did=H0C120130531ad\&doctype=ad .

${ }^{86}$ L. Fekete, N. Bouteldja \& N. Mühe, Alternative Voices on Integration in Austria, France, Germany, the Netherlands and the UK, (London, Institute of Race Relations, NEF and EPIM, 2010).
} 
Let us so conclude through quoting Stefan Jonsson's reading of the Stockholm riots ${ }^{87}$ with reference to the wisdom of Alain Bertho in Le temps des émeutes: ${ }^{88}$

That we live in the age of riots means that we do no longer - or still do not - live in the age of democracy. Therefore it is also not meaningful to combat or to crush rebellions. The best to do is to leave them space in politics, so that the silence and the noice can be converted into words. ${ }^{89}$

Acknowledgement:

This article is based on research financed by FORTE (earlier FAS), the Swedish Research Council for Health, Working Life and Welfare.

${ }^{87}$ S. Jonson, http://blog.liu.se/remeso/2013/05/21/det-stora-nejet-i-husby-fortsattning-i-upprorens-tid/ (2013)

${ }^{88}$ A. Bertho, Le temps des émeutes (Paris, Fayard, 2009)

${ }^{89}$ S. Jonsson http://blog.liu.se/remeso/2013/05/21/det-stora-nejet-i-husby-fortsattning-i-upprorens-tid/ 
